\title{
Gastric Parasitic Infection: Thinking outside the Box
}

\author{
Mara Sarmento Costa ${ }^{a}$ Nuno Almeida ${ }^{a} \mathrm{~b}$ \\ ${ }^{a}$ Department of Gastroenterology, Centro Hospitalar e Universitário de Coimbra, Coimbra, Portugal; ${ }^{\text {b}}$ Faculty of \\ Medicine, University of Coimbra, Coimbra, Portugal
}

Keywords

Strongyloides stercoralis · Strongyloidiasis · Stomach ulcer · Biopsy

\section{Infeção parasitária gástrica: Pensar fora da caixa}

\section{Palavras Chave}

Strongyloides stercoralis · Estrongiloidíase · Úlcera

gástrica· Biópsia

Strongyloides stercoralis is a nematode capable of penetrating the human skin through direct contact with contaminated soil. It migrates to the lung and the gastrointestinal tract, affecting mostly the small intestine, particularly the duodenum and upper jejunum, and rarely the stomach. It is endemic to tropical and subtropical regions and occurs sporadically in temperate areas such as southern Europe. From 1910 up to the 1980s, strongyloidiasis was endemic in Portugal, particularly in the central region, but since then only some sporadic cases have been published in the medical literature [1].

karger@karger.com www.karger.com/pjg

Karger $\stackrel{\text { ' }}{5}$

BOPEN ACCESS
(C) 2021 Sociedade Portuguesa de Gastrenterologia Published by S. Karger AG, Basel

This is an Open Access article licensed under the Creative Commons Attribution-NonCommercial-4.0 International License (CC BY-NC) (http://www.karger.com/Services/OpenAccessLicense), applicable to the online version of the article only. Usage and distribution for commercial purposes requires written permission.
Why is this parasitic infection relevant? Nowadays, immunosuppressed patients, due to malignancies, transplantation, or immunosuppressive drugs, are common in clinical practice. They are appealing hosts for autoinfection and, consequently, hyperinfection syndrome or disseminated strongyloidiasis. In fact, this parasite has the potential of causing lifelong infection, as it can remain quiescent for years, and autoinfection is a common pathway. On the other hand, mortality rates from hyperinfection syndrome are considerable, being as high as $80 \%$ [2, 3]. Finally, the diagnosis of this parasitic infection is frequently difficult since traditional parasitological fecal tests have a low sensitivity, and other diagnostic tools are frequently needed such as serologic tests and PCR-based assays to detect the DNA of the parasites in fecal matter [4].

Published in GE Portuguese Journal of Gastroenterology, Silva et al. [5] and Alcázar et al. [6] describe 2 cases of strongyloidiasis with different clinical manifestations and settings, but they have in common gastric involvement of the parasitic infection. First, the case presented by Silva et al. [5] seems to have an autochthonous origin, something that is now infrequent in the Iberian Peninsula. In contrast, the patient described by Alcázar et al. [6]

Mara João Sarmento da Costa

Department of Gastroenterology, Centro Hospitalar e Universitário de Coimbra Praceta Professor Mota Pinto

PT-3004-561 Coimbra (Portugal)

marajoaodacosta@ hotmail.com 
was a Dominican Republic native, and a recent study demonstrated a prevalence of $12 \%$ in Latin American migrants [7]. Second, in Silva et al. [5], the patient, who was immunocompetent, had a suspicious gastric ulcer with upper gastrointestinal bleeding. Suspecting a gastric neoplasia, a CT scan was performed and a lung nodule identified. However, subsequent evaluations determined that this nodule was squamous cell carcinoma and gastric histology was unremarkable for neoplastic cells but identified fragments of partially destroyed parasites [5]. Alcázar et al. [6] described a 60-year-old female with thrombotic thrombocytopenic purpura, who required high doses of corticosteroids and rituximab and was thus immunocompromised. She had hyperemesis and oral intolerance. Finally, gastric biopsies obtained during upper digestive endoscopy revealed the presence of this nematode in both patients, stressing the importance of such diagnostic methods in these uncommon cases.

In summary, S. stercoralis infection has a broad spectrum of clinical course. Patients may be asymptomatic, or present acutely or even chronically with fever. Gastrointestinal symptoms include vomiting, abdominal pain, bloating, diarrhea, and weight loss. Manifestations like potentially fatal gastrointestinal bleeding, intestinal obstruction, malabsorption syndrome, and sepsis have been reported. Laboratory findings, such as peripheral eosinophilia, are not specific or sensitive. Fecal sample examination has a low sensitivity, but repeated sampling can increase it. Serologic tests have a high negative predictive value that can be helpful to exclude strongyloidiasis, but definitive diagnosis usually requires visualization of the parasite in the stool or on biopsy. This last tool was fundamental in both case reports for diagnosis, given the high clinical suspicion necessary to reach a definitive di- agnosis in strongyloidiasis. There are no pathognomonic endoscopic findings. The endoscopic changes most described are exanthema, exudates, or friability and, more rarely, edema, erosion, or ulcer [8]. The case reported by Silva et al. [5] involved an uncommon diagnosis affecting a rare location and an even rarer endoscopic finding.

Ivermectin is the preferred treatment, with albendazole as a secondary option. Both patients underwent treatment with ivermectin, but in the woman treated by Alcázar et al. [6] albendazole was combined with ivermectin, since she was immunocompromised and an hyperinfection syndrome was assumed. Both authors describe a complete resolution of the clinical manifestations. In Silva et al. [5], a control endoscopy revealed complete healing of the gastric ulcer [9].

Given the low prevalence in our setting and the lack of specific clinical or laboratorial findings, diagnosing strongyloidiasis is a challenge. Even so, these reports highlight how this parasitic infection can be a forgotten cause of upper gastrointestinal bleeding and malabsorption syndrome as well as the importance of endoscopic biopsy for the diagnosis of gastrointestinal strongyloidiasis.

\section{Conflict of Interest Statement}

The authors have no conflicts of interest to declare.

Funding Sources

No funding was received.

Author Contributions

Both authors contributed to all stages of editorial composition.

\section{References}

1 Pinto J, Almeida P, Meireles D, Araújo A. Strongyloidiasis: A Diagnosis to Consider in Previously Endemic Regions in Portugal. Acta Med Port. 2020 Jan; https://doi. org/10.20344/amp.12960.

2 Rao S, Tsai H, Tsai E, Nakanishi Y, Bulat R. Strongyloides stercoralis Hyperinfection Syndrome as a Cause of Fatal Gastrointestinal Hemorrhage. ACG Case Rep J. 2019 Mar; 6(3):1-3.

3 Krolewiecki A, Nutman TB. Strongyloidiasis: A Neglected Tropical Disease. Infect Dis Clin North Am. 2019 Mar;33(1):13551.

4 Buonfrate D, Requena-Mendez A, Angheben A, Cinquini M, Cruciani M, Fittipaldo A, et al.
Accuracy of molecular biology techniques for the diagnosis of Strongyloides stercoralis infection-A systematic review and meta-analysis. PLoS Negl Trop Dis. 2018 Feb; 12(2):e0006229.

5 Silva RC, Carvalho JR, Crespo R, Martins JR, Zózimo N, Marinho RT. Stercoralis Gastric Ulcer - A Rare Cause of Upper Gastrointestinal Bleeding. GE Port J Gastroenterol. 2021. DOI: 10.1159/000509195.

6 Alcázar MM, Robles AG, Hidalgo JL, Fuentes DQ, Madonado AM. Strongyloides stercolaris with gastroduodenal involvement and complicated with SIAD: an unusual diagnosis to consider in immunosuppressed patients with hyperemesis and eosinophilia.
GE Port J Gastroenterol. 2021. DOI: $10.1159 / 000514015$.

7 Ramos-Sesma V, Navarro M, Llenas-García J, Gil-Anguita C, Torrús-Tendero D, WikmanJorgensen P, et al.; Corazones Sin Chagas Platform. Asymptomatic Strongyloidiasis among Latin American Migrants in Spain: A Community-Based Approach. Pathogens. 2020 Jun;9(6):E511.

8 Giuseppe S, Francesco C, Socrate P, Doriana V, Carlo S, Pierluigi C. Gastrointestinal: strongyloides stercoralis infestation. J Gastroenterol Hepatol. 2014;29(7):1340.

9 Greaves D, Coggle S, Pollard C, Aliyu SH, Moore EM. Strongyloides stercoralis infection. BMJ. 2013 Jul;347 jul30 3:f4610. 